\title{
PEMBAHARUAN PEMIKIRAN MAHMUD YUNUS TENTANG PENDIDIKAN ISLAM DAN RELEVANSINYA DENGAN PENDIDIKAN MODERN
}

\author{
Muhammad Abdullah \\ Universitas Yudharta Pasuruan \\ abdulloh@yudharta.ac.id
}

\begin{abstract}
This article aims to examine and explain about the movement of the thinking of Mabmud Yunus thoughts on Islamic education. Mabmud Yunus is a figure of the renewal of Islamic education derived from Minagkabau. The idea of Mabmud Yunus Received: in the field of Islamic education is generally strategic and is a pioneering work, in the February $21^{\text {th }} 2020$ sense that it has not been done by the Islamic education figures before. This type of research is literature research and data is derived from several secondary and tertiary

Revised: literature related to the thought of Mahmud Yunus and its relevance to modern March 28 2020 education. This study focused more on the attention and commitment of Mabmud Yunus to the development, improvement and development of Islamic education that can be seen further in some aspects of Islamic education thinking among others in terms of Accepted: Islamic education, objectives, curriculum, teaching methods educators and institutional May $20^{\text {th }} 2020$ Islamic education.

Keywords: renewal of thought, Mahmud Yunus, Islamic education
\end{abstract}

\section{PENDAHULUAN}

Pendidikan merupakan elemen yang esensial bagi kehidupan manusia. Dalam mempertahankan hidup agar tetap survive serta dalam menghadapi dan melestarikan alam semesta manusia membutuhkan pendidikan. Islam memandang pendidikan sangat penting bagi manusia dan Islam menempatkan pendidikan pada kedudukan yang tinggi dalam doktrinnya. ${ }^{1}$ Pendidikan juga merupakan strategi dalam meningkatkan kualitas suatu bangsa. Oleh karena itu kemajuan suatu bangsa dan kemajuan pendidikan merupakan determinasi kemajuan beberapa negara di dunia ini sebagai akibat dari itu maka perhatian suatu negara sangat besar dalam mengelola sektor pendidikan.

Pertumbuhan dan perkembangan pendidikan Islam di Indonesia terkait erat dengan kegiatan dakwah Islamiyah. Adapun Pendidikan Islam berperan sebagai sarana moderator dalam penyebaran ajaran Islam yang dapat disosialisasikan dan diakulturasikan kepada masyarakat dalam berbagai tingkatannya. Secara historis agama Islam masuk ke Indonesia ${ }^{2}$ dan berkembang di Nusantara ini tidak terlepas dari peran para ulama'. Para ulama' telah mendedikasikan hidupnya untuk menyebarkan Islam di Indonesia. Sejak masuknya Islam di Indonesia, pendidikan Islam telah ikut mengalami pertumbuhan dan perkembangan, karena berkat pendidikan Islam, transmisi dan sosialisasi ajaran Islam dapat dilaksanakan

\footnotetext{
${ }^{1}$ H Abuddin Nata, Sejarah Pendidikan Islam (Kencana, 2014).

2 Azmul Fahimi Kamaruzaman et al., "Al-Attas' Philosophy of History on the Arrival and Proliferation of Islam in the Malay World," International Journal of Islamic Thought 10 (2016): 1; T A Bachtiar, "Sejarah Nasional Indonesia Perspektif Baru," Bogor: Andalusia Islamic Education and Management Services (AIEMS) (2011).
} 
dan dicapai hasilnya sebagaimana realitas saat ini. Telah banyak lembaga pendidikan Islam yang bermunculan dengan formasi utamanya adalah memasyarakatkan ajaran Islam di Indonesia.

Pertumbuhan pendidikan Islam di Indonesia dapat dilihat salah satu diantaranya adalah di daerah Sumatra Barat tepatnya di Minangkabau yang merupakan daerah yang menjadi pusat perkembangan pendidikan Islam pada waktu itu, dimana surau ${ }^{3}$ menjadi salah satu lembaga pendidikan Islam terkenal sebelum adanya lembaga pendidikan madrasah di Minangkaban. ${ }^{4}$ Dalam perkembangannya, eksistensi surau merupakan lembaga yang sangat strategis bagi penyiaran agama Islam. Diantara beberapa tokoh yang telah berjasa dalam pengembangan dunia pendidikan Islam di tanah Minangkabau adalah seorang intelaktual bernama Mahmud Yunus. Mahmud Yunus adalah seorang tokoh pendidikan nasional, karyakaryanya banyak digunakan di sekolah-sekolah khususnya di lingkungan pendidikan pesantren.

Mahmud Yunus merupakan tokoh pendidikan Islam yang gigih dalam memperjuangkan masuknya pendidikan agama ke sekolah umum dan ikut berusaha memperjuangkan berdirinya Perguruan Tinggi Agama Islam Negeri (PTAIN). Perkembangan pemikiran Mahmud Yunus dalam pembaharuan pendidikan Islam di Indonesia merupakan kajian menarik untuk diteliti dan dijelaskan dalam lanskap paradigma pemikiran tokoh kotemporer di Indonesia untuk dikaji, tentang bagaimana gerakan pembaharuan pemikiran Mahmud Yunus dan bagaimana relevansinya dengan pendidikan modern.

\section{METODE}

Jenis penelitian yang akan digunakan adalah penelitian kepustakaan (library research) yaitu mengumpulkan data dan informasi dengan bantuan bermacam-macam materi yang terdapat di ruang perpustakaan, seperti buku-buku, majalah, dokumen catatan dari kisah sejarah dan lain-lain. ${ }^{5}$

Sumber data dalam jurnal ini terbagi menjadi dua, yakni data primer dan sekunder. Karena jenis penelitian ini termasuk penelitian kepustakaan, maka sumber primer terdiri atas buku-buku karya Mahmud Yunus, biografi Mahmud Yunus dan pemikiran Mahmud Yunus. Sedangkan sumber sekunder penelitian ini terdiri dari buku-buku literasi yang melengkapi pembahasan dalam penelitian ini terkait relevansi pemikiran Mahmud Yunus dengan Pendidikan Islam. Penelitian ini menggunakan pendekatan kualitatif, maka proses analisis data kualitatif mengarah pada unsur telaan seluruh data yang didapat dari beberapa sumber yakni beberapa buku baik sumber primer damupun sekunder, lankah selanjutnya adalah reduksi data, penyusunan satuan, kategorisasi dan yang terakhir adalah penafsiran data.

\section{HASIL DAN PEMBAHASAN}

\footnotetext{
${ }^{3}$ Azyumardi Azra, Pendidikan Islam: Tradisi Dan Modernisasi Menuju Milenium Baru (Logos Wacana Ilmu, 1999).

${ }^{4}$ Karel A Steenbrink, Beberapa Aspek Tentang Islam Di Indonesia Abad Ke-19 (Bulan Bintang, 1984).

${ }^{5}$ Mardalis, Metode Penelitian: Suatu Pendekatan Proposal (Bumi Aksara, 1995).
} 


\section{Biografi Singkat Mahmud Yunus}

Mahmud kecil dilahirkan di Sungayang Batusangkar Sumatra Barat pada hari Sabtu 16 Februari 1899. ${ }^{6}$ Secara geografis desa Sungayang berada kurang lebih 7 Km dari Kota Batusangkar sebagai pusat ibu kota Kabupaten Tanah Datar dan 12 Km dari Nagari Pagaruyung yang dahulunya merupakan pusat kerajaan Minangkabau.

Mahmud Yunus berasal dari keluarga sederhana yang taat menjalankan agama. Ayahnya bernama Yunus bin Incek seorang petani biasa dari suku Mandahiling. ${ }^{7}$ Sedangkan ibunya bernama Hafsah binti M. Thahir yang berasal dari suku Chaniago. Panggilan akrab ibunya di kalangan masyarakat sekitar dengan sebutan Posa. ${ }^{8}$ Latar belakang kakek beliau berasal dari pihak ibunya merupakan seorang ulama besar di Sungayang Batusangkar pada masa itu yang bernama Muhammad Ali dengan gelar Angku Kolok. Mahmud Yunus dibesarkan di tengah keluarga ibunya karena kedua orang tua Mahmud Yunus bercerai sejak ia masih kecil. ${ }^{9}$ Mahmud Yunus mewarisi bakat kakek beliau yang merupakan seorang ulama' besar di Sungayang, hal tersebut terbukti sejak kecil Mahmud Yunus memiliki potensi dan minat yang kecenderungan kuat untuk memperdalam ilmu keagamaan Islam.

Maka paman beliau yang bernama Ibrahim bergelar Dt. Sinaro Sati adalah seorang saudagar kaya raya di Batusangkar pada masa itu berusaha membantu Mahmud Yunus untuk membiayai segala kepentingan pendidikanya. Berkat dorongan kuat dari pamanya yang membuat Mahmud Yunus melanjutkan pendidikannya sampai ke luar negeri.

Pada akhir kehidupanya yakni di awal tahun 1970 kesehatan Mahmud Yunus menurun dan sering keluar masuk rumah sakit. Kemudian pada Tahun 1982, beliau memperoleh gelar doctor honoris causa di bidang ilmu tarbiyah dari IAIN Jakarta berkat karya-karyanya yang banyak berkontribusi dalam dunia pendidikan serta jasanya dalam pengembangan pendidikan Islam di Indonesia. Akhirnya pada usia ke-83 tepatnya pada tahun 1982 Mahmud Yunus menghembuskan nafas terahir. ${ }^{10}$

\section{Perjalanan Intelektual}

Mahmud Yunus mulai mempelajari ilmu al-Qur'an dan bahasa Arab sejak berusia 7 tahun. Surau merupakan lembaga pendidikan non formal pertama beliau yakni surau milik kakeknya sendiri yaitu M. Thahir bin Ali yang bergelar Engku Gadang. Berkat ketekunannya dalam waktu kurang dari satu tahun

\footnotetext{
${ }^{6}$ Tim Penulis IAIN Syarif Hidayatullah, "Ensiklopedi Islam Indonesia," Jakarta: Djambatan (1992).

${ }^{7} \mathrm{H}$ Ramayulis and Samsul Nizar, Ensiklopedi Tokoh Pendidikan Islam: Mengenal Tokoh Pendidikan Islam Di Dunia Islam Dan Indonesia (Quantum Teaching, 2005).

${ }^{8}$ Ibid.; Mahmud Yunus, “Riwayat Hidup Prof. Dr. H. Mahmud Yunus; 10 Pebruari 1899-16 Januari 1982” (Jakarta: PT Hidakarya Agung, 1982).

${ }^{9}$ Mestika Zed, "Riwayat Hidup Ulama Sumatera Barat Dan Perjuangannya" (Padang: Angkasa Raya, 2001).

${ }^{10}$ Ibid.
} 
beliau mampu menamatkan al-Qur'an. Pasca belajar mengaji dan menghafal al-Qur'an, Mahmud Yunus ditunjuk kakeknya untuk menjadi guru al-Qur'an. ${ }^{11}$

Lembaga formal pertama dijalani Mahmud Yunus pada tahun 1908 setelah warga Nagari Sungayang membuka Sekolah Desa di surau yang berada dibawah balai Senayan. Kegiatan pagi hari beliau belajar di Sekolah Desa, sedangkan di malam hari beliau tetap mengajar di surau kakeknya. Prestasi beliau tujukkan pada tahun pertama belajar di Sekolah Desa, beliau mampu menyelesaikan dalam waktu empat bulan, kemudian beliau memperoleh penghargaan naik ke kelas berikutnya. Bahkan di kelas tiga, beliau tetap bertahan dengan nilai tertinggi di antara teman-teman di kelasnya. ${ }^{12}$ Ketika sampai di kelas empat, Mahmud Yunus merasa jenuh dalam menuntut ilmu di Sekolah Desa, karena pengulangan dari beberapa pelajaran sebelumnya. Kemudian Mahmud Yunus mendengar kabar bahwa seorang ulama' terkemuka bernama H.M. Thalib Umar membuka madrasah di surau Tanjung Pauh, Sungayang, yakni Madras School. Setelah itu Mahmud Yunus pindah ke sekolah tersebut.

Setelah beberapa waktu belajar di Madras School dengan ketekunan dan prestasi yang gemilang, Mahmud Yunus tidak hanya ditunjuk menjadi tenaga pengajar yang menggantikan Syeikh H.M. Thalib Umar bahkan beliau juga dipercaya untuk memimpin Madras School. Kemudian perjalanan intelektual Mahmud Yunus berlanjut pada tahun 1924 M. pada waktu itu bersamaan beliau dalam menunaikan ibadah haji ke Makkah sekaligus beliau melanjutkan pendidikannya ke tingkat yang lebih tinggi di Negara Timur Tengah, yaitu Mesir tepatnya di Universitas Al-Azhar. ${ }^{13}$ Mahmud Yunus kembali memperlihatkan prestasi yang istimewa, setelah satu tahun masa belajar, beliau mencoba kemampuannya dengan masuk ujian akhir untuk menamatkan pendidikan di Universitas Al Azhar dan mendapatkan Syahâdah 'Alimiyah sebagai ijazah tertinggi di Universitas Al Azhar. ${ }^{14}$

Pada tahun 1925 beliau berhasil memasuki lembaga pendidikan Madrasah Ulya. Beliau memilih jurusan Tadris (Keguruan). ${ }^{15}$ Perkuliahan dilaluinya dengan baik, bahkan pada tingkat terakhir, dia memperoleh nilai tertinggi pada mata kuliah insyâ'(mengarang). Setelah menjalani masa pendidikan dan menimba berbagai pengalaman di Mesir, kemudian pada tahun 1931 beliau kembali ke Indonesia.

\section{Warisan Intelektual}

Kegiatan menulis tersebut dijalani Mahmud Yunus sampai masa pensiun dalam karirnya. Bahkan, pada tahun-tahun terakhir kehidupannya. ${ }^{16}$ Secara klasifikasi beberapa bidang keilmuan yang ditekuni

\footnotetext{
11 Shalahuddin Hamid and Iskandar Ahza, Seratus Tokoh Islam Yang Paling Berpengarub Di Indonesia (Intimedia Cipta Nusantara, 2003).

12 Yunus, "Riwayat Hidup Prof. Dr. H. Mahmud Yunus; 10 Pebruari 1899-16 Januari 1982."

${ }^{13}$ Ramayulis and Nizar, Ensiklopedi Tokoh Pendidikan Islam: Mengenal Tokob Pendidikan Islam Di Dunia Islam Dan Indonesia.

${ }^{14}$ Yunus, "Riwayat Hidup Prof. Dr. H. Mahmud Yunus; 10 Pebruari 1899-16 Januari 1982."

15 Abuddin Nata, Tokoh-Tokoh Pembaruan Pendidikan Islam Di Indonesia (Divisi Buku Perguruan Tinggi, RajaGrafindo Persada, 2005).

${ }^{16}$ Ramayulis and Nizar, Ensiklopedi Tokoh Pendidikan Islam: Mengenal Tokob Pendidikan Islam Di Dunia Islam Dan Indonesia.
} 
beliau diantaranya: bidang pendidikan, hukum Islam (fiqib), tafsir, akhlak, ilmu jiwa, sejarah Islam dan lain-lain. ${ }^{17}$ Dalam bidang Pendidikan, meliputi: Pengetahuan Umum dan Ilmu Mendidik, Metodik Khusus Pendidikan Agama, Pengembangan Pendidikan Islam di Indonesia, Pokok-Pokok Pendidikan dan Pengajaran, AtTarbiyyah wa at-Ta'lim, Pendidikan di Negara-Negara Islam dan Intisari Pendidikan Barat, Metodik Khusus Bahasa Arab, Kamus Arab Indonesia, Durusu al-Lughah al-'Arabiyyah (juz I,II dan III).

Bidang Fiqh, diantaranya: Marilah Sembabyang (Juz I, II, III dan IV), Puasa dan Zakat, Haji ke Mekkah, Hukum Warisan dalam Islam, Hukum Perkawinan dalam Islam, Pelajaran Sembahyang untuk Orang Dewasa, Manasik Haji untuk Orang Dewasa. Dalam bidang Tafsir, adalah: Tafsir al-Qur an al-Karim 30 juz, Tafsir al-Fatihah, Tafsir Ayat Akhlak, Juz 'Amma dan Terjemahannya, Tafsir al-Qur'an Juz 1-10, Pelajaran Huruf Al-Qur`an, Kesimpulan Isi Al-Qur`an, Alif Ba Ta wa Juz 'Amma, Mubadarat al-Israiliyyat fi at-Tafsir wa al-Hadith.

Adapaun Bidang Akhlak, diantaranya: Keimanan dan Akhlak (Juz I, II, III dan IV), Beriman dan Berbudi Pekerti, Lagu-Lagu Baru Pendidikan Agama Akhlak, Akhlak Bahasa Indonesia, Moral Pembangunan dalam Islam, Akhlak dan karya lainnya. Sedangkan dalam bidang Sejarah, adalah: Sejarah Pendidikan Islam, Sejarah Pendidikan Islam di Indonesia, Tarikh al-Fiqhu al-Islami, Sejarah Islam di Minangkabau, Tarikh al-Islam dan lain sebagainya karya dalam bidang keagamaan lainnya.

\section{Pembaharuan Pendidikan Mahmud Yunus}

Pada permulaan abad ke-20 masyarakat Islam Indonesia telah mengalami beberapa perubahan baik dalam bentuk kebangkitan agama maupun pencerahan. Salah satu fokus diantaranya adalah dorongan kuat untuk melawan penjajah Belanda. Dalam melakukan perlawanan tidak mungkin bangsa Indonesia harus mempertahankan segala aktivitas perlawanan tersebut dengan cara tradisional dalam melawan kekuatan-kekuatan kolonialisme Belanda. Perlawanan tersebut mendorong umat Islam untuk mengadakan berbagai pembaharuan.

Pembaharuan yang dilakukan pada waktu itu adalah sector pendidikan. Karena pendidikan merupakan sektor strategis dalam mempengaruhi paradigma pemikiran masyarakat Indonesia. Secara otomatis perubahan Islam berjalan seiring dengan pembaharuan pendidikan Islam. Kemudian muncul gerakan pembaharuan pendidikan Islam di berbagai daerah di Indonesia. Mahmud Yunus merupakan salah satu tokoh pembaharu pendidikan Islam yang berasal dari Sumatra Barat. Kondisi pendidikan Islam di Indonesia pada awal abad ke-20 pada umumnya masih bercorak tradisional. Kurikulum yang digunakan pada berbagai lembaga pendidikan Islam masih bercorak dikotomis antara ilmu agama dan ilmu umum. Adapun orientasi pembelajaran masih bertumpu pada penguasaan materi melalui hafalan dan verbalistik, yakni mampu mengucapkan tapi tidak mengerti maksud, tujuannya, dan mengamalkannya. Sebagai

${ }^{17}$ Nata, Tokoh-Tokoh Pembaruan Pendidikan Islam Di Indonesia. 
contoh pengajaran bahasa Arab lebih banyak menekankan aspek gramatika tanpa diimbangi kemampuan menggunakannya dalam bentuk ucapan dan tulisan. Disamping itu pula pada saat itu belum ada lembaga pendidikan tinggi Islam di Indonesia.

Gerakan pembaharuan nyata yang dilakukan Mahmud Yunus berlihat pada masa jenjang karirnya. Pada tahun 1943 ketika beliau diangkat menjadi penasehat residen mewakili Majelis Islam Tinggi. Dalam kedudukan sebagai penasihat residen tersebut Mahmud Yunus memanfaatkan kekuasaannya untuk melakukan pembaharuan pendidikan dengan berusaha memasukkan pendidikan agama di sekolahsekolah pemerintah. Kemudian pada tahun 1947 Mahmud Yunus pindah ke kota Pematang Siantar dan ditunjuk sebagai Kepala Bagian Islam pada Jawatan Agama Provinsi Sumtera. Dalam kedudukan demikian beliau mengusulkan kepada PPK (Kanwil P\&K) untuk memasukkan mata pelajaran agama ke dalam daftar pengajaran di sekolah-sekolah negeri mulai dari tingkat Sekolah Dasar sampai Sekolah Menengah Atas. ${ }^{18}$

Karir dalam jabatan selanjutnya adalah pada tahun 1951 Mahmud Yunus dipercaya oleh Menteri Agama yakni K.H. Abdul Wahid Hasyim untuk menjadi kepala penghubung pendidikan agama pada Departemen Agama di Jakarta. Pada waktu menjabat ini beliau mengeluarkan kebijakan-kebijakan, diantaranya: ${ }^{19}$

1. Mewujudkan peraturan bersama Menteri P dan K dan Menteri Agama tentang pendidikan Agama di sekolah sekolah swasta.

2. Mendirikan Pendidikan Guru Agama (PGA) pada tahun 1951 di delapan kota.

3. Menetapkan rencana pendidikan Agama Islam di sekolah-sekolah dasar, dari kelas IV-VI, demikian juga di sekolah menengah.

4. Mewujudkan peraturan bersama Menteri P dan K beserta Menteri Agama tentang peraturan Perguruan Tinggi Agama Islam Negeri (PTAIN) di Yogyakarta.

\section{Pemikiran Mahmud Yunus Tentang Pendidikan Islam dan Implikasinya dengan Pendidikan}

\section{Modern}

1. Pengertian dan tujuan Pendidikan Islam

Pendidikan Islam diterjemahkan Mahmud Yunus sebagai suatu bentuk pengaruh yang terdiri dari ragam pengaruh yang terpilih berupa dorongan dan bimbingan berdasarkan tujuan yang dapat membantu peserta didik agar berkembang secara jasmani, akal dan pikiran. Dalam proses pendidikan terdapat upaya yang harus dicapai agar diperoleh hasil yang maksimal dan sempurna, yakni tercapailah kehidupan harmoni secara personal dan sosial.

\footnotetext{
18 Ibid.

19 Ibid.
} 
Segala bentuk kegiatan yang dilakukan menjadi lebih sempurna, kokoh, dan baik bagi masyarakat. ${ }^{20}$ Dengan demikian sampailah kita kepada cita-cita yang tinggi untuk menjadikan manusia sebagai insan kamil. Salah satu pokok untuk mendapatkan kemajuan dalam kehidupan ialah bila orang itu bertubuh tegap dan sehat. "akal yang sehat dalam tubuh yang kuat". ${ }^{21}$

Menurut Mahmud Yunus seorang pendidik tidak akan maju dalam usahanya dalam membimbing anak didiknya apabila tidak mengetahui pertumbuhan jasmani anak-anak serta apa yang dibutuhkan oleh jasmani itu. Maka kesehatan anak-anak penting sekali dijaga dalam mendidik mereka, karena kebahagiaan akan tercapai jika diiringi dengan kesehatan. Selanjutnya Mahmud Yunus membagi pendidikan Islam dalam tiga bagian yakni pendidikan akal, akhlak dan masyarakat.

Berkaitan dengan tujuan pokok pendidikan Islam, Mahmud Yunus merumuskan bahwa pendidikan Islam bertujuan untuk kecerdasan perseorangan dan untuk kecakapan mengerjakan pekerjaan. ${ }^{22}$ Menurut beliau bahwa beribadah itu merupakan salah satu perintah Islam, dan pekerjaan duniawi yang menguatkan pengabdian kepada Allah SWT juga merupakan perintah Islam. Dengan demikian kekuatan yang berupa pengabdian kepada Allah juga termasuk dalam kategori tujuan pendidikan Islam.

Oleh sebab itu tujuan pendidikan Islam menurut Mahmud Yunus adalah menyiapkan anak didik agar di waktu dewasa kelak mereka cakap melakukan pekerjaan dunia dan amalan akhirat sehingga tercipta kebahagiaan bersama baik di dunia maupun di akhirat. Untuk itu anak didik harus diajarkan Keimanan, Akhlak Ibadah dan Isi al-Qur'an serta harus dididik untuk mengerjakan salah satu dari macam-macam profesi seperti bertani, berdagang, bertukang, menjadi guru, dan lain sebagainya sesuai dengan bakat, minat dan kemampuan masing-masing anak didik. ${ }^{23}$

2. Kurikulum Pendidikan Islam

Dalam kurikulum pendidikan Islam Mahmud Yunus merupakan orang yang berjasa dan orang pertama yang mecetuskan kurikulum yang terpadu (integtated), yaitu memasukan kurikulum ilmu agama dan ilmu umum di lembaga pendidikan Islam, khususnya dalam pembelajaran bahasa bahasa Arab. Pada mulanya bahasa Arab lebih banyak didukung aspek gramatika tanpa dimbangi dengan kemampuan menggunakannya dalam bentuk ucapan dan tulisan.

Aspek kurikulum Mahmud Yunus pada saat itu yang tergolong baru adalah yang berkaitan dengan kurikulum bahasa Arab, bahwa pengajaran bahasa Arab dilakukan secara integral dari cabangcabang ilmu bahasa Arab dengan tidak memisah-misahkannya satu persatu. Menurut Mahmud yunus dalam pengajaran bahasa Arab adalah bukan hanya mengajarkan muthala'ah saja tapi di dalam

${ }^{20}$ Mahmud Yunus dan Qosim Bakri, At-Tarbiyah Wa At-Ta'lim (Gontor: Matba'ah Dar as-Salam, n.d.).

${ }^{21}$ Mahmud Yunus, Pokok-Pokok Pendidikan Dan Pengajaran (Hidakarya Agung, 1978).

22 Ibid.

${ }^{23}$ Ibid. 
pengajaran itu juga dibahas tentang qawaid, insyak, qira'ah dan lainnya dari cabang ilmu bahasa Arab. Disamping itu pula dalam pengajaran bahasa arab kepada peserta didik dipadukan dengan menerapkanya dalam kehidupan sehari-hari.

Penerapan kurikulum bahasa Arab tersebut Mahmud Yunus telah mengarang beberapa buku pelajaran bahasa Arab sebanyak 4 jilid. Dalam buku tersebut Mahmud Yunus menerapkan metode pengajaran bahasa Arab dengan memadukan unsur membaca, menulis, memahami dan bercerita dengan menggunakan bahasa Arab.

\section{Metode Pendidikan Islam}

Metode menurut Mahmud Yunus adalah jalan yang akan ditempuh oleh guru untuk memberikan berbagai pelajaran kepada pesetra didik dalam berbagai jenis mata pelajaran. Jalan itu adalah khittah (garis) yang direncanakan sebelum masuk ke dalam kelas dan dilaksanakan dalam kelas sewaktu mengajar. ${ }^{24}$ Dengan menggunakan kata khittah yang berarti langkah-langkah, maka dapat disimpulkan kembali bahwa metode menurut Mahmud Yunus adalah langkah-langkah yang dilakukan oleh pendidik sebelum masuk kelas dimana langkah tersebut direncanakan untuk menghindari berbagai kesalahan-kesalahan yang dimungknkan terjadi didalam kelas pada waktu pelajaran dilaksanakan.

Dengan demikian, terdapat dua hal penting yang terkait metode sebagaimana yang disebutkan oleh Mahmud Yunus, yaitu:

a. Perencanaan sebelum masuk kelas, rencana ini mencakup keseluruhan aspek yang direncanakan oleh pendidik, seperti lama pelajaran apa yang dipelajari, waktu pelajaran, pendekatan-pendekatan dan asas-asasnya dan langkah-langkah apa saja yang akan dilakukan mulai dari awal sampai habis pelajaran.

b. Pada saat pembelajaran dilaksanakan. Dalam hal ini ada tiga waktu yang menjadi perhatian penting bagi guru. Yakni:

1) Pra pembelajaran, yaitu beberapa hal yang harus diperhatikan pendidik saat masuk kelas sebelum pelajaran dimulai, misalnya memperhatikan kondisi psikologi peserta didik, membangkitkan gharizah (semangat), meneguhkan hati dan memberikan motivasi dalam diri peserta didik. Pada saat inilah yang paling penting bagi pendidik dalam memberikan motivasi sehingga mampu meningkatkan minat belajar bagi murid.

2) Saat pembelajaran, jika pada pra pembelajaran telah berjalan dengan lancar dan mendapat tanggapan yang positif, maka inti pelajaran yang akan disampaikan akan mudah, pada saat inilah seorang pendidik menggunakan metode atau strategi yang tepat guna dalam menyampaikan pelajaran dengan baik.

${ }^{24}$ Mahmud Yunus, "Metodik Khusus Pendidikan Agama," Jakarta: Hidakarya Agung (1983). 
3) Pasca pembelajaran, yakni beberapa hal yang dilakukan oleh pendidik setelah selesainya proses pembalajaran, sebelum pendidik meninggalkan kelas, metode yang digunakan pendidik adalah menyimpulkan materi pembelajaran, memberikan pertanyaan, menyuruh murid mempelajari pelajaran yang akan datang dan lainnya.

Mahmud Yunus juga menambahkan bahwa menjadi pendidik janganlah menggunakan satu metode saja secara terus-menerus, karena hal tersebut dapat membosankan peserta didik. Pendidik dituntut mampu menggunakan bermacam-macam metode, bahkan mampu menciptakan metode baru yang lebih baik dan lebih baik dari metode-metode lama. Tujuan utamanya adalah peserta didik dapat belajar dengan gembira, mengerti dengan mudah, ilmu itu menjadi miliknya serta mengerti dengan mudah, ilmu itu menjadi miliknya serta mempertajam otaknya, memperbaiki budi pekertinya, sehat jasmani dan rohaninya dan suka menuntut ilmu selama hidupnya. ${ }^{25}$

4. Pendidik

Menurut Mahmud Yunus Pendidik adalah orang yang menjadi perantara dalam menyampaikan pengetahuan kepada peserta didik. Dia yang memilih ukuran pengetahuan yang cocok dan pantas diberikan untuk peserta didiknya. ${ }^{26}$ Pandangan Mahmud Yunus tentang pendidik meliputi dimensi profesionalitas, dimensi pedagogis, dimensi kepribadian, dan dimensi sosial yang mencerminkan keutuhan diri pendidik.

a. Dimensi Profesional, menurut Mahmud Yunus profesioanl adalah pendidik selalu mempersiapkan profesi sebagai pelayanan bagi peserta didiknya, maka seorang yang bergelut dalam profesi pendidik harus mengetahui dan mengukur kemampuannya serta mempersiapkan segala hal yang berhubungan dengan profesi kependidikannya, sehingga dengan persiapan yang matang akan berpengaruh pada keberhasilan proses pendidikan tersebut. Disamping itu pula dianjurkan bagi peserta didik untuk selalu mempersiapkan materi dalam pembelajarannya, dan selalu memperbarui pengetahuannya sehingga selalu berkembang kemampuan dan semakin luas pengetahuannya. ${ }^{27}$

b. Dimensi Kepribadian, karakter kepribadian seorang pendidik menurut Mahmud Yunus diantaranya adalah: pendidik harus penyayang dan murah senyum, sabar, disiplin dan sungguh-sungguh, tegas dan bersuara lantang, teliti terhadap kegiatan peserta didik dan bertubuh sehat. ${ }^{28}$

c. Dimensi Pedagogis, menurut Mahmud Yunus seorang pendidik harus menguasai kaidah-kaidah pendidikan, diantaranya adalah ilmu dasar pendidikan yang sangat berguna bagi seorang pendidik, dikarenakan beberapa faktor, yakni: pertama, menghbungkan pendidik yang satu dengan yang lain, artinya membantu pendidik dengan variasi percobaan dalam mengajar. Kedua, membimbing

\footnotetext{
${ }^{25} \mathrm{Ibid}$.

${ }^{26}$ Bakri, At-Tarbiyah Wa At-Ta'lim.

${ }^{27} \mathrm{Ibid}$.

${ }^{28}$ Ibid.
} 
pendidik dalam mancari metode yang efektif dan efisien. Ketiga, memungkinkan pendidik untuk meneliti beberapa metode pembelajaran dan memilih yang baik untuk mempermudah dalam mencapai tujuan pembelajaran. ${ }^{29}$

d. Aspek Sosial, menurut Mahmd Yunus aspek sosial pendidik adalah seorang pendidik adalah sebagai pengganti ayah dalam mendidik anaknya. Dan dari sini jelas bahwa lembaga pendidikan tidak akan bias melaksanakan tugasnya dengan baik kecuali terdapat hubungan yang kuat dengan pihak keluarga rumah. Hendaknya pendidik menjalin hubungan (pertemuan) dengan ibu bapak anak didik (walinya) serta meminta kepada mereka supaya pelajaran agama atau akhlak yang telah dipelajari disekolah diimplementasikan anak-anak mereka dirumah. ${ }^{30}$

5. Kelembagaan Pendidikan Islam

Lembaga pendidikan Islam di indonesia pada tahun 1931 menurut Mahmud Yunus memasuki warna baru yang disebut modernisasi pendidikan Islam di Indonesia. ${ }^{31}$ Di mana pada tahun itu Mahmud Yunus memperkenalkan Kulliyah al-Muallimin al-Islamiyah (KMI) di mana pelaksanaan pengajaran dilaksanakan di kelas-kelas dengan jadwal dan kurikulum yang sudah ditetapkan, jenjang kelaspun diatur menurut jenjangnya masing-masing.

Dalam bidang kelembagaan, Mahmud Yunus termasuk orang yang mempelopori perlunya mengubah sistem pengajaran dari yang bercorak individual seperti sorogan atau bandungan yang biasanya diterapkan di pesantren kepada sistem pengajaran klasikal. Dalam metode sorogan ini belum dikenal adanya sistem kelas. Lembaga pendidikan klasikal tersebut banyak berpengaruh pada perkembangan pendidikan Islam "Modern” di Indonesia salah satunya melalui alumninya KH. Imam Zarkarsyi, salah satu pendiri Pondok Modern Darussalam Gontor Ponorogo Jawa Timur. Di tahun 1936 Pesantren Gontor sudah mengikuti kurikulum dan sistem pendidikan normal Islam (modern), sistem pendidikan di gontor yang identik dengan sistem klasikan dan berasrama, kitab-kitab kuning dikemas ke dalam buku-buku teks pelajaran yang disesuaikan dengan jenjang pendidikan santrinya.

Menurut Mahmud Yunus sistem pembelajaran klasikal ini merupakan bentuk pembaharuan karena berbeda dengan sistem pesantren model lama. Sistem klasikal dikembangkan secara terpimpin dan terorganisir dalam bentuk penjenjangan kelas dalam jangka waktu yang ditetapkan dianggap lebih efisien, karena dengan biaya dan waktu yang relatif sedikit dapat menghasilkan produk yang besar dan bermutu.

Dari beberapa pemikiran yang ditawarkan Mahmud Yunus diatas terbukti masih relevan dengan teori-teori dalam pendidikan islam saat ini, dimana banyak pemikir-pemikir yang mempunyai persamaan persepsi dengan Mahmud Yunus. Dan pemikiran tersebut sangat cocok untuk menjadi bahan rujukan

\footnotetext{
29 Ibid.

${ }^{30}$ Yunus, "Metodik Khusus Pendidikan Agama."

${ }^{31}$ Nata, Sejarah Pendidikan Islam.
} 
dalam rangka mengembangkan pendidikan islam kedepan. Karena konsep yang dirumuskan Mahmud Yunus bersifat menyeluruh. Mencangkup aspek kognitif, afektif dan psikomotorik. Dalam aspek kognitif dalam kegiata belajar mengajar Mahmud Yunus menekankan pada pendalaman materi untuk membawa peserta didik berfikir kritis, sehingga membawa para peserta didik menggunakan penalarannya semaksimal mungkin. Pada aspek afektif, Mahmud Yunus menekankan pada pentingna metoda pengajaran pendidik. Sedangkan pada aspek psikomotorik dalam kegiatan belajar mengajar Mahmud Yunus menekankan pada pengembangan kecakapan peserta didik dan dapat mengaplikasikan ilmu yang dipelajarinya dalam kehidupan sehari-hari.

Adapun keunikan paradigma pemikiran Mahmud Yunus apabila dibandingkan dengan ahli pendidikan pada masanya adalah banwa Mahmud Yunus memiliki perhatian dan komitmen yang tinggi terhadap upaya membangun, meningkatkan dan pengembangan pendidikan agama Islam sebagai bagian integral dari sistem pendidikan yang diperuntukkan bagi seluruh masyarakat Indonesia, khususnya yang beragama Islam. Gagasan dan pemikirannya dalam bidang pendidikan secara keseluruhan bersifat strategis dan beliau merupakan karya perintis, dalam arti belum pernah dilakukan oleh tokoh-tokoh pendidikan Islam sebelumnya. Sebagai salah satu tokoh pemimpin dan ilmuwan yang handal dan disegani baik oleh bangsa Indonesia sendiri maupun oleh dunia Internasional. ${ }^{32}$

\section{KESIMPULAN}

Dari beberapa uraian diatas maka dapat disimpulkan bahwa Mahmud Yunus dapat dikelompokkan sebagai pembaharu dalam pendidikan Islam di Indonesia. Hal ini terlihat dari pendidikan dan gagasannya dalam melakukan perombakan sistem pendidikan Islam yang ketika itu masih tradisional. Perhatian dan komitmen Mahmud Yunus terhadap pembangunan, peningkatan dan pengembangan pendidikan Islam tersebut dapat dilihat lebih lanjut dalam beberapa aspek pendidikan diantaranya dari segi pengertian pendidikan Islam, tujuan, kurikulum, metode pengajaran, pendidik dan kelembagaan pendidikan Islam. Sebagai seorang ahli pendidikan Islam, konsep-konsep pendidikan Mahmud Yunus sangat komprehensif, karena sebagai seorang ahli dan praktisi pendidikan, beliau juga seorang pejabat Negara yang selalu berpikir tentang kemajuan pendidikan Islam di Indonesia. Dengan demikian konsep-konsep pendidikan Mahmud Yunus selalu berangkat dari idealitas empiris.

\section{DAFTAR PUSTAKA}

Azra, Azyumardi. Pendidikan Islam: Tradisi Dan Modernisasi Menuju Milenium Baru. Logos Wacana Ilmu,

\footnotetext{
32 Abuddin Nata, "Pemikiran Para Tokoh Pendidikan Islam: Seri Kajian Filsafat," Pendidikan Islam. Jakarta: PT. Raja Grafindo
} Persada (2001). 
1999.

Bachtiar, T A. "Sejarah Nasional Indonesia Perspektif Baru." Bogor: Andalusia Islamic Education and Management Services (AIEMS) (2011).

Bakri, Mahmud Yunus dan Qosim. At-Tarbiyah Wa At-Ta'lim. Gontor: Matba'ah Dar as-Salam, n.d. Hamid, Shalahuddin, and Iskandar Ahza. Seratus Tokoh Islam Yang Paling Berpengaruh Di Indonesia. Intimedia Cipta Nusantara, 2003.

Hidayatullah, Tim Penulis IAIN Syarif. “Ensiklopedi Islam Indonesia.” Jakarta: Djambatan (1992).

Kamaruzaman, Azmul Fahimi, Aidil Farina Omar, Roziah Sidik, and Mat Sidek. “Al-Attas' Philosophy of History on the Arrival and Proliferation of Islam in the Malay World." International Journal of Islamic Thought 10 (2016): 1.

Mardalis. Metode Penelitian: Suatu Pendekatan Proposal. Bumi Aksara, 1995.

Nata, Abuddin. "Pemikiran Para Tokoh Pendidikan Islam: Seri Kajian Filsafat." Pendidikan Islam. Jakarta: PT. Raja Grafindo Persada (2001).

. Tokoh-Tokoh Pembaruan Pendidikan Islam Di Indonesia. Divisi Buku Perguruan Tinggi, RajaGrafindo Persada, 2005.

Nata, H Abuddin. Sejarah Pendidikan Islam. Kencana, 2014.

Ramayulis, H, and Samsul Nizar. Ensiklopedi Tokoh Pendidikan Islam: Mengenal Tokoh Pendidikan Islam Di Dunia Islam Dan Indonesia. Quantum Teaching, 2005.

Steenbrink, Karel A. Beberapa Aspek Tentang Islam Di Indonesia Abad Ke-19. Bulan Bintang, 1984.

Yunus, Mahmud. "Metodik Khusus Pendidikan Agama.” Jakarta: Hidakarya Agung (1983).

—. Pokok-Pokok Pendidikan Dan Pengajaran. Hidakarya Agung, 1978.

“Riwayat Hidup Prof. Dr. H. Mahmud Yunus; 10 Pebruari 1899-16 Januari 1982.” Jakarta: PT Hidakarya Agung, 1982.

Zed, Mestika. "Riwayat Hidup Ulama Sumatera Barat Dan Perjuangannya." Padang: Angkasa Raya, 2001. 